外国人対応医療と総合健診

\title{
生涯現役社会の実現に向けた取り組みと国際展開
}

西川 和見 ${ }^{1)}$

\section{$\gg$ 生涯現役社会の実現に向けて}

我が国の高齢化率（65歳以上人口）は27\%を超 え、2060年には 4 割近くになる見込みです。高齢者
が稀であった19世紀型の社会から高齢者が社会の主 要構成員となる21世紀型社会への転換（図1）を世 界で初めて経験するのが日本です（図 2)。これは 一人一人の長寿化の賜物であり、否定すべきもので

\section{図 1 日本の人口構造（年齢層別人口割合の遷移）}

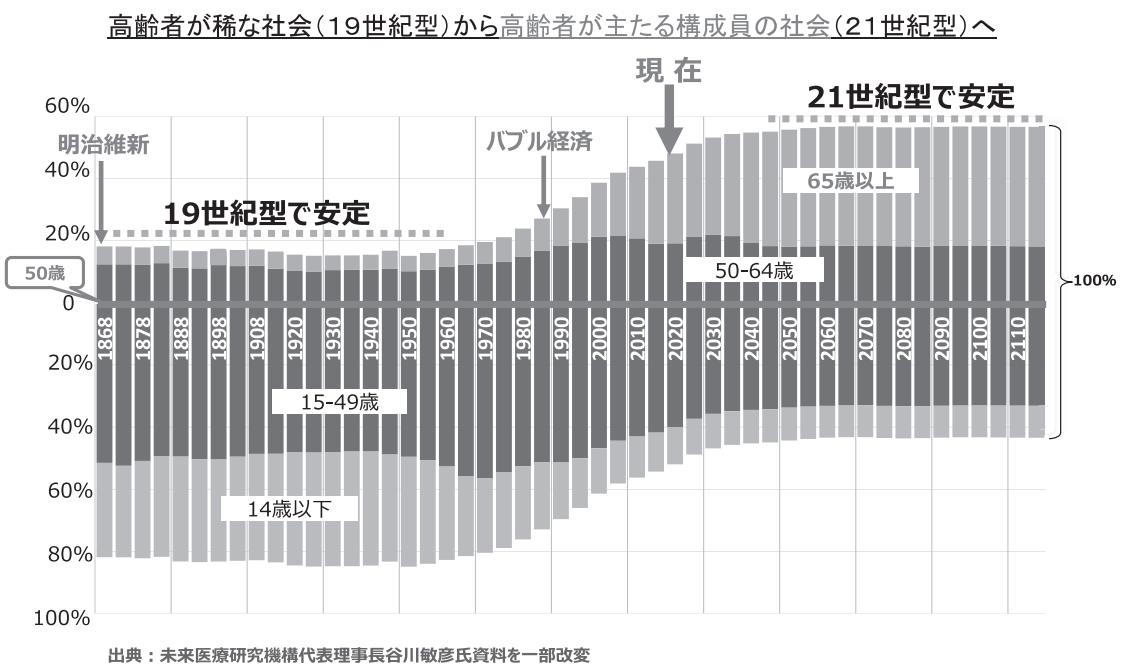

\section{図 2 主要国における高齢化の進展}

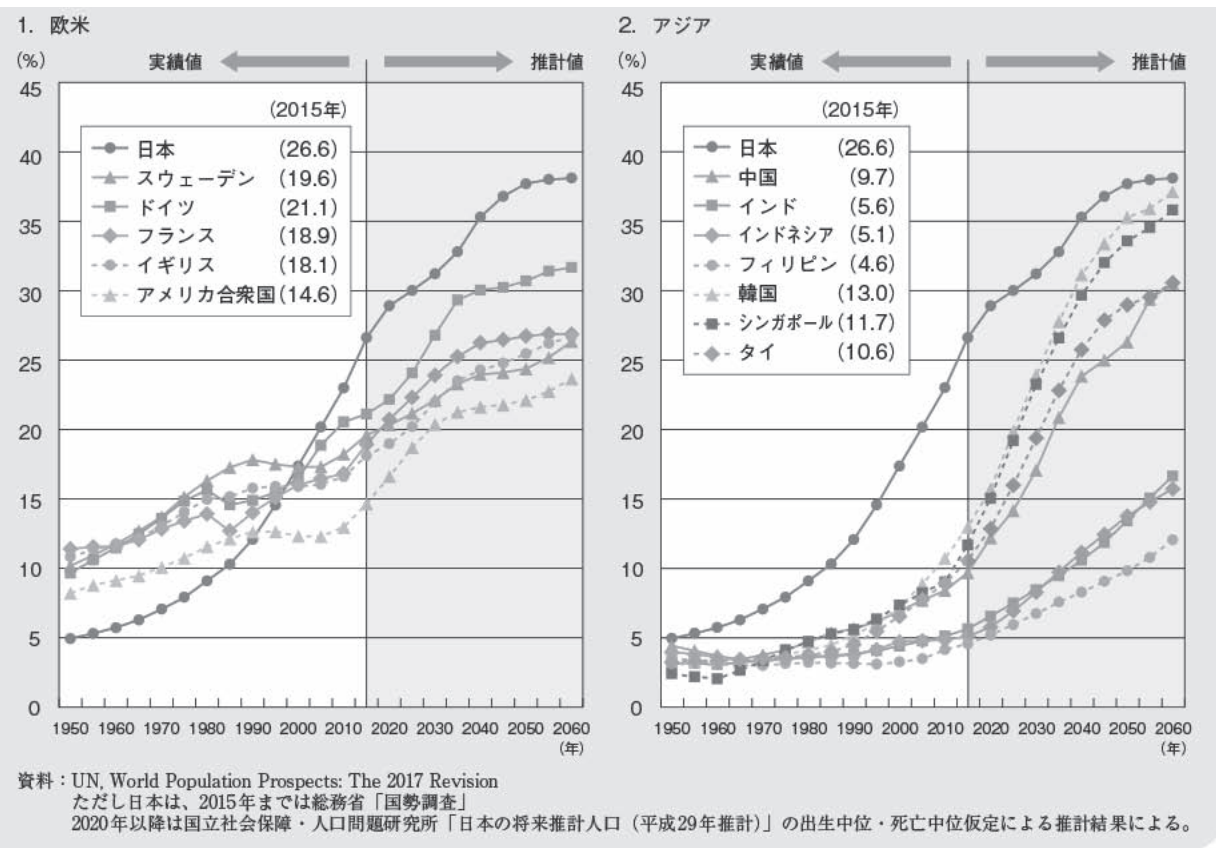

1 ）経済産業省大臣官房 
はなく、喜んで受け入れた上で、経済成長や地域社 会の持続性をどのように達成すべきか、に注力すべ きです。そのためには、健康面、能力面、社会面で 国民が活躍できる基盤づくりが久かせません。日本 政府が、人生の最終段階まで笑顔で活躍できる社 会、「生涯現役社会」の達成を、社会福祉政策だけ でなく、経済政策の柱に掲げ、予防・健康づくりか ら、働き方改革、新たな教育のあり方等に力を入れ ている背景です。

昨年秋に、国内外の医療関係者・アカデミア、グ ローバル企業・スタートアップ、政府関係者が東京 に集まり、「2 nd Well Aging Society Summit」を開 催しました。2 日間に渡り、22力国、650人の方が 参加し、国民の健康の向上と、新たなイノベーショ ン・市場の創出を同時に達成することで、高齢化を 乗り越えよう、と熱心な議論が行われました。医療 関係者だけでなく、ダボス会議の事務局である世界 経済フォーラムのメンバーのように、マクロ経済や イノベーションに関する幅広い関係者が参加された ことも、この分野への関心の高さを伺わせるもので した。教育・まちづくりから、予防、早期発見、診 断、治療、リハビリ、生活支援まで、生涯を通じ て、国民を健康にしていく解決策に世界的な関心が 高まりつつあり、世界第一の超高齢社会である我が 国が国内外に貢献できる潜在力は強いものがありま
す。この潜在力を現実のものとするため、学問、業 種、国境の壁を越えて、新しいネットワークと解決 策を生み出していくことが急務です。

\section{\「予防 / 進行抑制 / 共生型」の 健康医療システム}

人生 100 年時代で年齢に関係なく活躍できる社会 を作るためには何をすべきでしょうか。健康度、 Quality of Life（QOL）の観点から見てみましょう。 東京大学の秋山先生の調査をべースとすると、65歳 の時点で QOL が高い方は、比較的高い QOL を保つ 一方、65歳の時点で QOL が低い方は、寝たきりの 時間が長くなります。「健康づくりは若いうちから」 取り組むことが重要と言えます。また、秋山先生の 調査では、日本人男性の 10 人に一人老年期も高い QOLを保っています。その背景には、社会性が共通 要素としてあります。「いつまでも社会と関わる」 ため、高齢者が社会に役割を持つ、体が弱っても社 会との接点を持ち続けられるような環境が重要です (図 3 )。

従来の制度、ライフスタイル、ワークスタイル、 考え方などを、新しい超高齢社会に適合するように 変容させていく必要があります。健康医療面も新た な取り組みが必要です。戦後、我が国における健 康／医療上の課題は、結核や肝炎といった感染症対

\section{图 3}

人生 100 年時代では、「健康づくりは若いうちから」、「いつまでも社会とかかわる」が重要。

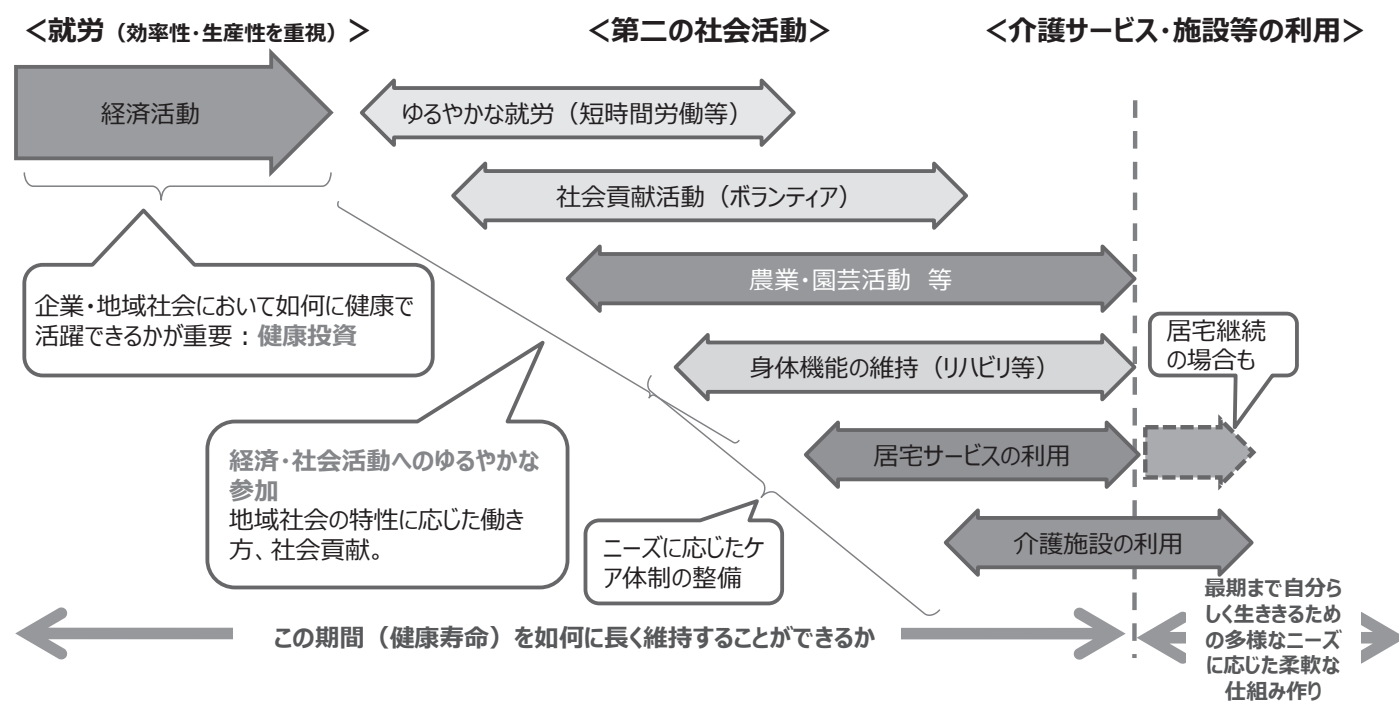


・単一標的型疾患への対応に加え、新たな課題（多因子関連型疾患）への対応が重要。

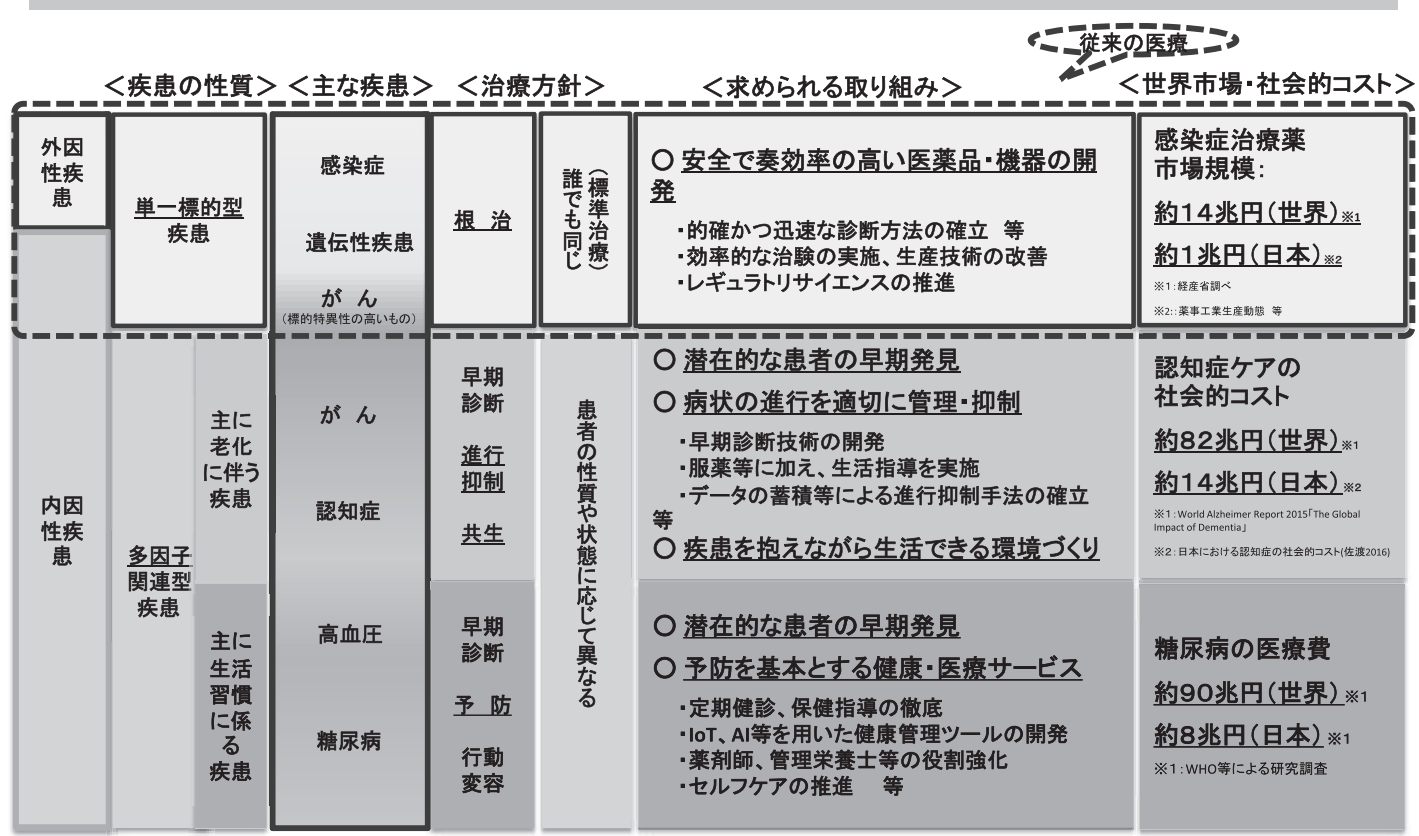

策でした。感染症の根治を目指し、公衆衛生の徹 底、診断／治療体制の確立、新薬の開発に力を入 れ、日本の医療レベルは格段に向上し、OECD でも トップクラスです。一方で、先進国や高齢化してい くアジアも含め、新たな課題は、 2 型糖尿病のよう な生活習慣病、認知症のような老化に伴う疾患にな ります。単一の病原菌等ではなく、日常生活のあり 方を含む複数の要因が絡まって発生する多因子型疾 患と呼ばれ、病院で医師に薬を処方してもらうだけ では足りず、病気になる前からの取り組み（予防） や生活習慣を変容が必要になります。また、認知症 やフレイルなど、老化に伴う疾患は、加齢とともに 進行することを「止める」ことは難しく、予防に力 を入れつつ、その進行を遅らせ（進行抑制）、さら に疾患を持ちながらも社会と関与できるようにする (共生) が重要になります。人生 100 年時代では、診 断／治療に加え、「予防／進行抑制／共生型」の健 康医療システムの構築が重要です (図 4 )。

\section{ヤ・ 健康経営の取り組み}

「健康づくりは若いうちから」はどう実現するの でしょうか。国民皆保険に基づくへルスチェック体 制が整っています。食文化や教育面でも、これまで の成果が見られます。一方で改善要素が大きいのは
職域です。人生の多くの時間を過ごす職域では、長 時間労働、ストレス、生活習慣のみだれ等の課題が 山積しています。

労働安全衛生法による規制や、保険者による保健 サービスも実施されていますが、「健康無関心層」 と呼ばれる層は厳然と残っています。さらなる改善 には、経営陣や会社/組織側の協力が必要だ、との 声もあります。こうした問題意識の下、政府では 「健康経営」の普及を 7 年前に始めました。従業員 の健康管理を経営課題として捉え、戦略的に取り組 む。つまり、経営陣や会社／組織にとって、これま で「コスト／義務」であったものを、「投資」とし て捉え、従業員を健康にして、生産性や創造性を上 げ、業績をあげる／強い組織をつくる、という考え 方です。

世界的な産業構造の変化、新興国の台頭、国内の 人材不足の状況を受け、各企業は、生産性の向上に 大きな関心を持っています。従業員教育、R \& D 投 資、設備投資などの選択肢がありますが、その選択 肢に「健康投資」を加えるのです。Johnson and Johnson は、 1 ドルの健康投資は 3 ドルのリターン をもたらす、と試算しています。米国商工会議所の 調査では、職域の健康管理の不備により各国の GDP が 5 〜 \%下げているとされます。健康投資は企業 論理や経済政策から言っても合理的です。 
こうした考え方は、日本企業にとって新しいもの ではありません。従業員やその家族を大事にする経 営は「日本型経営」とされてきたものの重要な要素 です。ものづくりの現場で言われる「5S（整理、整 頓、清掃、清潔、しつけ)」は、産業安全に多大な 貢献をしていますが、規制があるからやる、のでは なく、生産性の向上、取引先からの評価を勘案し、 自主的に取り組み、高めてきたものです。「産業安 全」で前例があるなら、「産業保健」でも同様の取 り組みを進めることが可能だと考えています。

健康経営は、上場企業の 4 社に一社、中小企業ま で含めると 4 万近い法人が採用し、足元でも数が増 えています。従業員が健康になり、業績もあがり、 また、そうした活動が将来の元気な高齢者を生み出 す、という点で、全てに良い効果を生み出すもので す。日本商工会議所の三村会頭、日本医師会の横倉 会長が共同代表となり、経済産業省と厚生労働省が 支える「日本健康会議」の枠組みは、健康経営の質 を高め、裙野を広げる力強いエンジンとなっていま す。職域の健康管理に積極的な法人が増え、予防の ための新たな市場が生まれています。ウェアラブル の売り上げは、米国では個人購入が 9 割を占めます が、日本では半分以上が、企業や保険者による購入 です。生活習慣病対策のサービスが拡大する一方、 女性の職域での体調管理のためのサービスやメンタ ルヘルス対策など、「我慢してきたもの」「放置され ていたもの」への対応も拡大しています。

健康経営は、これからアジアや世界に拡大してい くと考えています。企業が人「財」育成を重視する 環境は、OECD 諸国だけでなく、少子高齢化が急速 に進むに新興国にも、当てはまるでしょう。日本の ものづくり企業が中国、アセアン、インドで「 $5 \mathrm{~S} 」$ を広めたように、健康経営が拡大していく。いくつ かの企業はすでに取り組みを始めています。予防 サービスへの需要も拡大するでしょう。中長期的な トレンドですが、この分野への投資が日本企業の競 争力を左右するでしょうし、将来の国際協力の柱に なっていくと期待しています。

\section{$\longrightarrow$ 認知症対策}

「いつまでも社会とかかわる」ために必要なこと は何でしょうか。緩やかな就業選択肢の提供、地域 社会との接点の拡大などが考えられますが、その ハードルになるものが認知症です。これまでの分析
では、加齢とともに認知機能が低下する、特に 80 代 や90代で進行する方が多いと言われ、人生100年時 代における大きな課題です。認知機能が低下しても 笑顔で暮らされている方も㧍られ、認知症を「治 す」必要はあるのか、という議論もありますが、認 知症が大きな社会コストを生み、個人としても、社 会としても重要な課題となっていることは事実で す。

他の疾患と同様、認知機能の低下メカニズムを解 読し、特効薬を作ろう、という動きも進んでいま す。ただ、治療薬の開発は中長期的課題と言われて います。日本では数百万の認知症の方が扔られ、団 塊の世代の高齢化に連れ、その数は増加していきま す。薬の開発を待つだけでなく、薬以外の手段によ る認知症の予防／認知症との共生が重要です。こう した背景から、一昨年の未来投資戦略には、認知症 の方にやさしい製品／サービス開発の必要性が盛り 込まれました。その後、認知症対策関係閣僚会合が 発足し、認知症対策大綱が制定され、認知症との共 生/予防の取り組みが開始しています。認知症の予 防については、食事、運動、脳トレーニング、生活 習慣対策、社会性など、様々な手段で生活を改善す る(多因子介入) ことで、症状の進行を遅らせる取 り組みを、日本医療研究開発機構、国立長寿医療研 究所、損保ジャパンを中心に、産官学のコンソーシ アムで開始しています。フィンランドの FINGER Study など世界の先行研究と連携しながら、1,000人 規模の臨床研究を行い、評価指標の確立を目指す 3 年間の大プロジェクトです。また、認知症との共生 については、日本認知症官民協議会において、認知 症の方や家族の方の意見も踏まえながら、認知機能 の低下を補完する製品／サービスの開発／標準化が 進められています。財産管理や買い物支援、認知症 にやさしい住宅や都市のデザイン、認知機能が低下 した方とのコミュニケーション支援などで、安価で 使いやすい製品/サービスを社会実装することを目 指しています。

例えば、お隣の中国では、日本式介護についての 関心が高く、すでに多くの民間レベル、政府レベル の取り組みが進んでいます。これまで日本が生み出 してきた、自立支援型介護、在宅介護、デイケアセ ンターといったコンセプトや介護事業運営のあり方 は、足元での協力の柱です。さらにその先には、認 知症対策が重要な協力の柱になっていくと考えてい ます。 


\section{$\gg$ 公的保険外サービス}

人々の健康を維持し、社会の安定を確保するため には、誰でも病気になれば治療を受けられる制度の 存在は不可欠であり、日本の国民皆保険制度は素晴 らしいものです。一方、予防／進行抑制／共生型の 健康医療システムを実現するためには、公的保険制 度に頼るだけではなく、普段から健康になっていく ことが重要です。そのためのサービスは、個人の嗜 好や環境にあったものが適切であり、若い人向けか らお年寄り向けまで、様々なものが民間サービスと して提供されています。公的保険の対象とはならな いが、国民の健康度の向上に寄与する民間サービス を、政府は「公的保険外サービス」と呼び、その品 質向上と適正な使用を推進しています。生活全般に 関わることであり、全てを規制することは不可能で す。市場経済の力を適正に使う、すなわち、民間主 体で品質向上の取り組みが促進され、適正な仲介者 （プロの目）を通じて、国民／消費者に届く流通の 仕組みの確立を目指しています。政府の次世代へル スケア産業協議会では、民間による品質向上の取り 組みの参考として「へルスケアサービスガイドライ ン等のあり方」を制定し、普及を図っています。ま た、地域の医師会や自治体の社会福祉部の方など、 地域住民と接点を持つ方に、公的保険外サービスを 選定し、個人に届ける「仲介者」として活躍いたた くことを期待しています。もちろん、保険、流通、 メディア等の民間事業者も適切な形で「仲介者」を 担っていただくことが期待されます。

こうした公的保険外サービスは、中国をはじめと するアジアで健康医療に対するニーズが高まるにつ れ、より一層、市場を拡大していくでしょう。日本 式の食事や美容にブランド力があるように、日本式 のヘルスケアサービスがアジアの方に好んで使われ ることは望ましい方向です。手厚い公的保険制度が 整っていない国に㧫いても、こうしたサービスの活 用により予防に力を入れることができます。日本の 専門家とともに開発された質の高い公的保険外サ一 ビスが、アジアや世界に拡大していくことを期待し ています。

\section{ヤ・゙ジタルヘルス}

Society5.0は、多様性を深める社会の中で個人が テクノロジーを活用してスマートに生きることを目
指すもの、と言えます。ヘルスケア分野こそ、AIや ICT の活用が重要な領域であり、予防、診断、治 療、共生のすべての面でデジタルの活用が進んでい ます。予防や共生では、個人の健康／医療情報のみ ならず、日常的な生活デー夕を組み合わせること で、行動変容やリスクの早期発見を実現することが できます。診断、治療においても、医療の専門分化 が進む中で、デジタルの活用により、医師が患者の 状態をより全体的に把握し、診断／治療の質を向上 させることができます。高齢化の進展は、都市部で は医療 /介護の需要を増大させ、病院 /介護施設の 供給不足を生み出し、地方では高齢者人口の減少に より、病院／介護施設の倒産を招く、と指摘されて います。テクノロジーの活用により、時間制約や空 間制約を乗り越えることができれば、需給ギャップ の緩和に貢献できます。超高齢社会では、現場の人 材不足を補うロボットやセンサーの活用は「あった らいいな」というレベルではなく、「マスト」の課 題です。慢性期病対策で、デジタルを活用し、医師 が患者の日常生活をモニタリングし、介入すること も期待されます。

日本では、ヘルスケア分野での Society5.0の実現 に向け、多くの産業が参入し、超高齢社会のニーズ に根ざしたイノベーションが次々と生み出されてい ます。国に抒いても、保険者等が保有する健診情報 を個人に提供する、MRI、CT、内視鏡といった画像 データを分析し AI を構築する、健康医療情報、遺 伝子情報、生活情報などを一体的に収集し、解析す るなど、様々なプロジェクトを進めています。

その中で、我が国の共通の特徴は、法に基づく個 人情報の適正な保護、高い倫理観と能力に基づく質 の高い研究開発、公的保険制度に基づくデー夕管 理／標準化のしやすさ、といった点です。世界から 信頼される「質の高いデジタルヘルス」が進んでい ると言えます。デジタル化に抒いて日本は「出遅れ ている」と言われ、デジタルヘルス分野でも日本以 上に多くの投資が行われ、収拾するデー夕量や分析 スピードで日本を上回る国もたくさんありますが、 そこと張り合うのではなく、日本は、個人に信頼さ れる「質の高いデジタルヘルス」を生み出すことで、 補完的な関係を構築していくべきだと考えます。

\section{ゆ・アジア健康構想・アフリカ健康構想 —}

以上、超高齢社会に向けた日本の新しい取り組み 
アジアでの富士山型のヘルスケアのイメージ

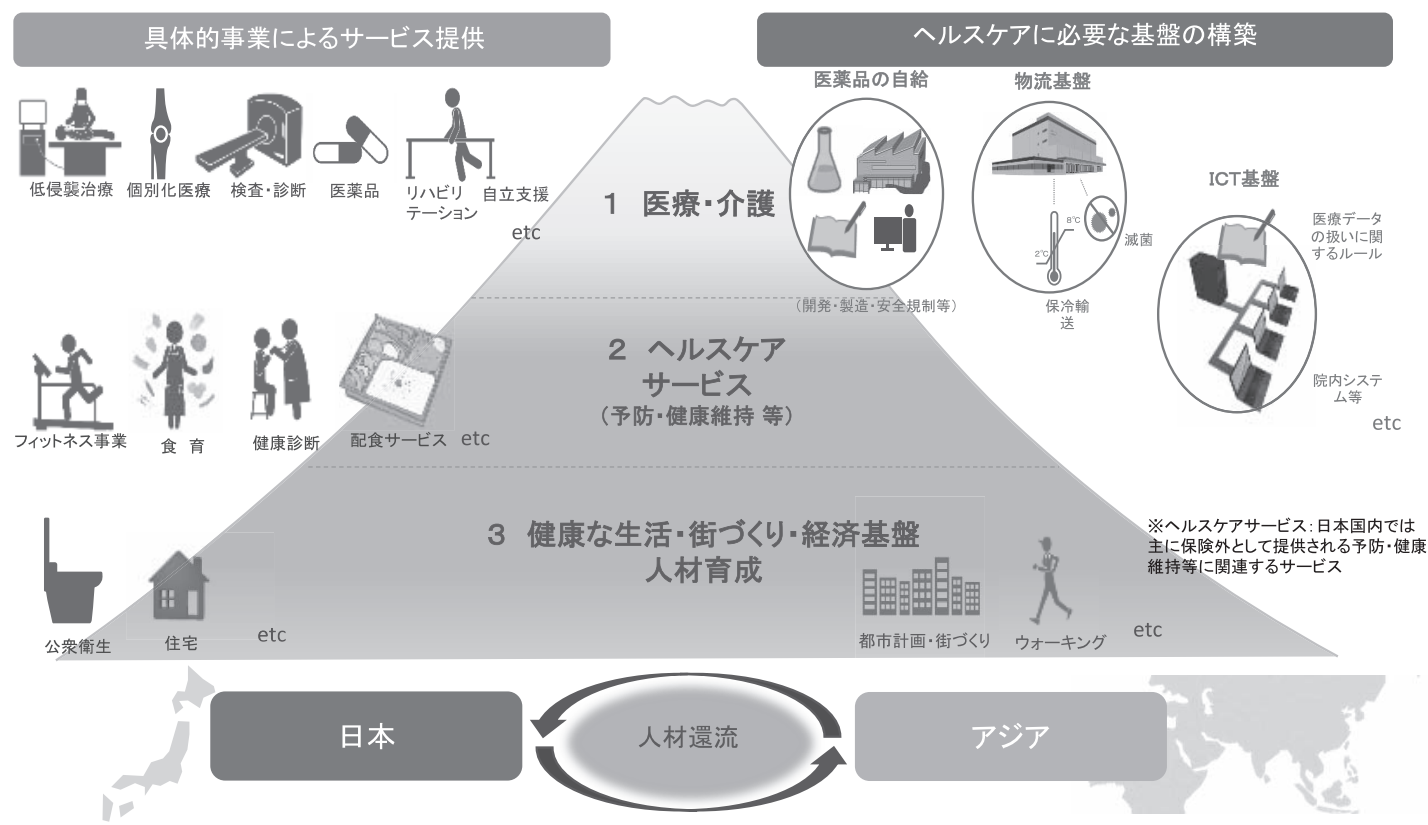

例を紹介しましたが、既に実現した健康／医療／介 護システムをアジアや世界に共有していくことも、 もちろん必要です。政府は、アジア健康構想・アフ リカ健康構想を制定し、アジアやアフリカに対し て、富士山型のへルスケア、すなわち、医療を頂上 に、これを支える䂆防やケアのサービス、さらに町 づくりや消費財といった裙野の広いサービスまで含 め、日本の健康長寿を実現した幅広い産業を共有し ていくこととしています（図 5)。担い手として、 JETRO や JICA といった機関に加え、医療関連産 業の国際展開を目的に、医療関係者と産業関係者で 構成する Medical Excellence Japan（MEJ）という 団体も設立されています。政府内では、内閣官房の 下に、厚生労働省、経済産業省、外務省といった省 庁が連携して取り組む体制が構築されています。

例えば中国との関係では、介護サービス協力も数 多く進んでいます。ジェトロを中心に、各地で介護 サービス協力のマッチングイベントが開催されてい ます。昨年からは国家発展改革委員会と経済産業省 が覚書を結び、政府レベルで協力を本格化させてい ます。また、高度医療、遠隔診療、健診、医療ツー リズムなど幅広い分野で医療協力が進んでいます。 がんの治療や高度な外科手術を受けるために日本を 訪問される中国の方も年々増加しています。フィリ ピンやタイ、ベトナム、インドネシア、インドと
いった国との関係では、病院、健診技術、医療機器 の国際展開が進んでいます。足下ではデジタルヘル スやジェネリック医薬品に関する協力を進めたい、 という機運も高まっています。アフリカとの関係で は、TICAD（アフリカ開発会議）の枠組みの下に、 ヘルスケア協力に関する官民コンソーシアムを構築 し、協力がスタートしています。

PMDA の理事長を 10 年勤められ、現在 MEJ の理 事長をされている近藤先生は、「日本は欧米と並ぶ 3 大医療圈」と言われます。新興国の経済発展は素 晴らしいものがありますが、新薬を安定的に開発で きるレベルになるには時間がかかります。社会貢献 という意味でも、ビジネスの面でも、ヘルスケア分 野は我が国がアジアやアフリカと関係を深めるべき 分野だと言えます。多くの企業、専門職、アカデミ アの皆様が連携して、この分野を前に進めていただ くことを期待しています。

\section{$\rightarrow$ Healthcare Innovation Hub}

我が国は国民皆保険に支えられた地域医療が全国 津々浦々に広がっています。医学、工学、薬学、生 物学といったアカデミクスのレベルも高く、世界一 の超高齢社会としての社会ニーズも突出して高い状 態にあります。 
こうした課題先進国、医療先進国としての我が国 の強みを活かし、多くのイノベーションが我が国か ら生まれ、社会実装され、世界に展開していくこと が、日本の医療・介護サービスの質を向上させると いう点からも、国富を拡大させるという点からも重 要です。経済産業省、厚生労働省、内閣官房といっ た関係省庁と、医療界・アカデミア、産業界・金融
界が協力し、「Healthcare Innovation Hub（略称 innohub)」を昨年夏に立ち上げています。100を越 える企業・団体が参加し、国内外のヘルスケアイノ ベーションの結節点となる組織です（図 6〜8)。 イノベーション支援に関する情報提供、グローバル シンポジウムの開催、ネットワーキング支援など、 幅広い活動を実施しています。現在、学会や病院の

-ベンチャー企業に加えて、イバーションを必要とする多様な団体から幅広く相談を受付。

- サポーター（メンター）を中心に、サポーター団体と連携し、国内外のネットワークを活用して支援。

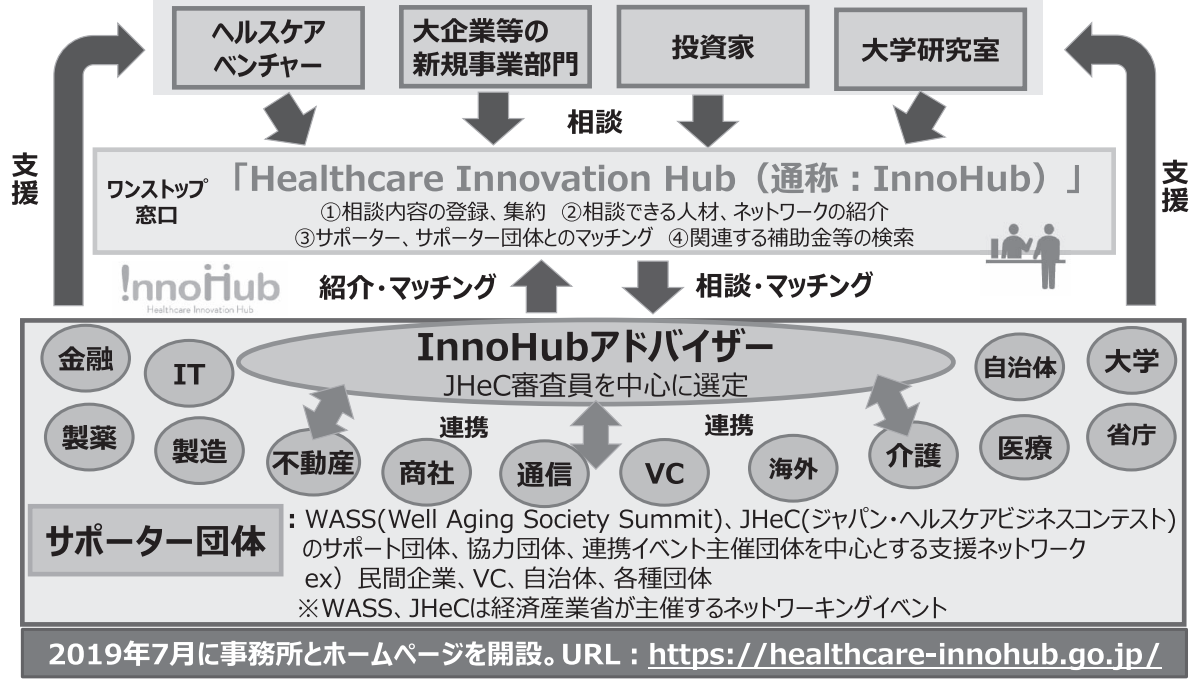

・ 15名にアドバイザーとしてInnoHubの活動にコミットいただいています。

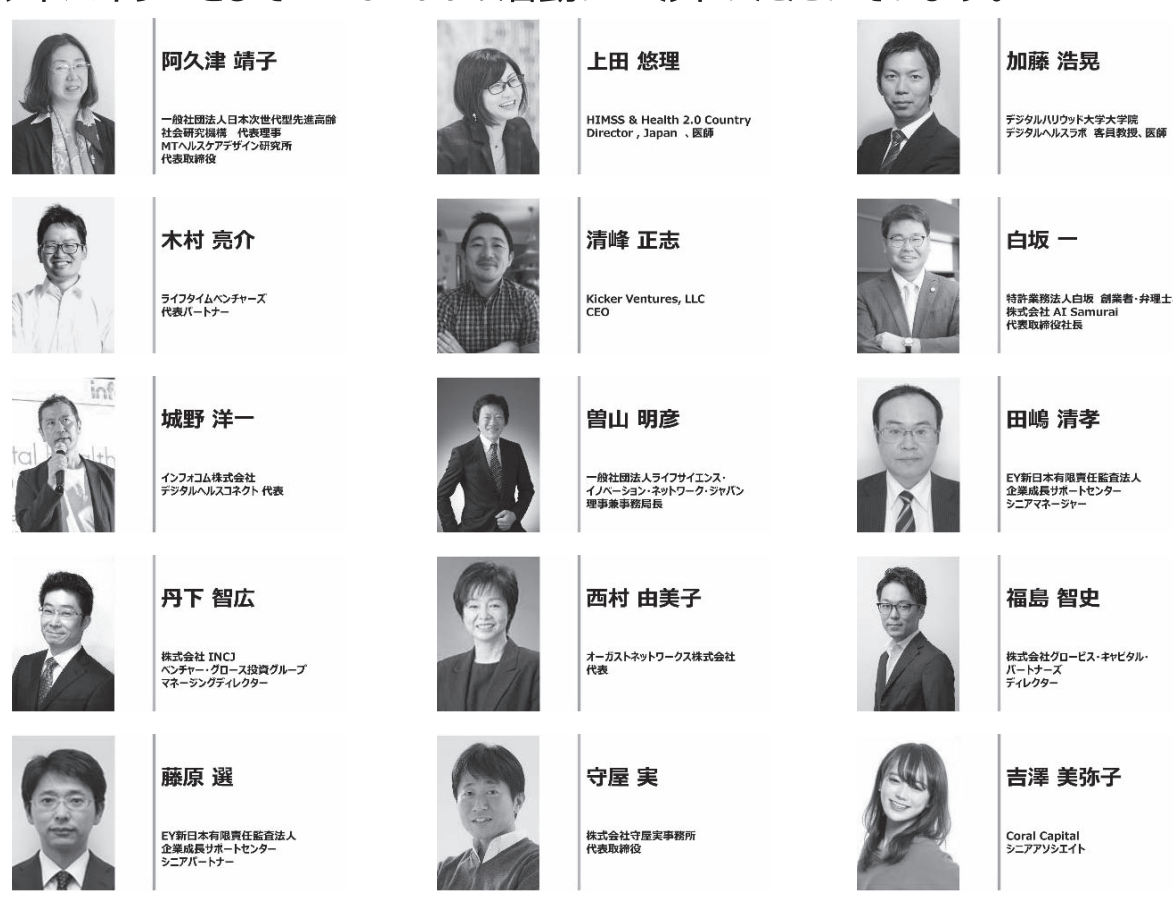


アカデミア関係者の参加拡大を進めているところで あり、日本総合健診医学会の皆様におかれても、ご 関心を持っていただければ幸いです。
著者の COI（conflict of interest）開示：本論文発表内容 に関連して特に申告なし

図 8 InnoHub サポーター団体 一覧

2月19日時点で119団体に、InnoHubサポーター団体として登録いただいています。 InnoHubサホ⿺ーター団体は、継続的に募集しています。

【vC】

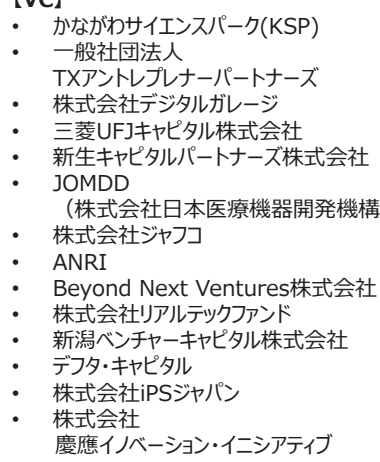

\section{【金融】}

SMBC日興証券株式会社

株式会社みずほ銀行

- 三菱UFJリース株式会社

- 三并住友フアイナンス\&リース株式会社

【通信】

- KDDI株式会社

・・フトバンク株式会社

【食品メーカー】

・江崎グリコ株式会社

【製薬メーカー】

【製薬メーカー】
帝人ファーマ株式会社

小林製薬株式会社

田辺三菱製薬株式会社

ロート製薬株式会社

カイゲンファーマ株式会社

大正製薬株式会社

シミツクホールディングス株式会社

ハバルティスファーマ株式会社

興和株式会社

アステラス製薬株式会社

小野薬品工業株式会社

ヤンセンファーマ株式会社

ファイザー株式会社

\section{【医療機器·そのほかメーカー】}

富士フイルム株式会社

株式会社ワコール

株式会社日立製作所

JOHNAN株式会社

オムロンヘルスケア株式会社

株式会社フイリップス・ジャパン

アリオン株式会社

オリンパス株式会社

テルモ株式会社
【コンサルティング.監查法人など】

有限責任 あずさ監査法人

Public Intelligence Japan株式会社 グロービッツFDAコンサルティング

、株式会社メディヴァ

・合同会社ソシオタンク

メドピア株式会社

TC3株式会社

株式会社インディージャパン

株式会社HORBA

プレモパートナー株式会社

株式会社大和総研ビジネス・イノベーション

株式会社メプラジャパ

デロイトトーマツコンサルテイング合同会社

株式会社JTB総合研究所

株式会社デイジット

日鉄ソリューションズ株式会社

【商社】

- 住友商事株式会社

丸紅株式会社

センチュリーメディカル株式会社

豊田通商株式会社

【システム】

·株式会社インターネットイニシアティブ

【大学/研究機関・医療機関·調剤薬局.

介護関連施設】

株式会社八ーフ・センチュリー・モア

日本調剂株式会社

医療法人社団プラタナス

奈良東病院グループ

国立がん研究センター

国立大学法人東京医科歯科大学

医療法人さわらび会

\section{【公的機関·自治体など}

工業技術研究院

島根県

高石市健幸のまちづくり協議会

東京都

仙台フインランド健康福祉センター

- 福井県

松本地域健康産業推進協議会

神戸市

ウエルネスバレー推進協議会

(愛知県大府市・東浦町)

札幌市

公益財団法人大阪産業局

豊田市役所/豊田地域医療センタ一

福岡地域戦略推進協議会

LIP(リップ).横浜 (横浜市経済局)

秋田県

宇部市
【保険】

・ SOMPOホールディングス株式会社

住友生命保険相互会社

日本生命保険相互会社

- 第一生命保険株式会社

・ MS\&ADインシュアランスグループ

ホールディングス株式会社

- 三井住友海上火災保険株式会社

- 大同生命保険株式会社

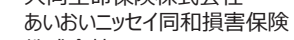

株式会社

・ 三井住友海上あいおい生命保険

株式会社

- アフラック生命保険株式会社

- 明治安田生命保険相互会社

- 東京海上日動火災保険株式会社

\section{【自動車】}

- 卜ヨ多自動車株式会社

【広告】

- 竹田印刷株式会社

【福利厚生】

株式会社イーウェル

【弁護士事務所】

- 渥美坂井法律事務所・外国法共同事業

\section{【業界団体·その他団体】}

- 一般財団法人日本ヘルスケア協会

- 日本医療政策機構

ライフサイエンス・イノ゙ーション・

ネットワーク・ジャパン (LINK-J)

一般社団法人

ジャパンバイオデザイン協会

一般財団法人日本規格協会

- 日本セルフケア推進協議会

- 一般社団法人

医療データベース協会

一般社団法人

日本ヨガメディ仂協会

株式会社 沖縄TLO

一般社団法人

日本医療機器産業連合会

始動 $\times$ 医療

公益財団法人

京都高度技術研究所

一般社団法人

中国経済連合会

- WOMB Business Incubator

2020年2月19日時点 